\section{$\underset{\substack{\text { hommes } \\ \text { \& migrations }}}{ }$}

\section{Hommes \& migrations}

Revue française de référence sur les dynamiques

migratoires

\section{$1284 \mid 2010$}

Migrations et environnement

\title{
Tout ce qui brille
}

Film français de Géraldine Nakache et Hervé Mimran

\section{André Videau}

\section{(2) OpenEdition \\ 12 Journals}

Édition électronique

URL : http://journals.openedition.org/hommesmigrations/1275

DOI : 10.4000/hommesmigrations. 1275

ISSN : 2262-3353

Éditeur

Musée national de l'histoire de l'immigration

Édition imprimée

Date de publication : 1 mars 2010

Pagination : 199

ISSN : 1142-852X

\section{Référence électronique}

André Videau, «Tout ce qui brille», Hommes \& migrations [En ligne], 1284 | 2010, mis en ligne le 29 mai 2013, consulté le 22 septembre 2020. URL : http://journals.openedition.org/hommesmigrations/1275 ; DOI : https://doi.org/10.4000/hommesmigrations.1275

Ce document a été généré automatiquement le 22 septembre 2020.

Tous droits réservés 


\section{Tout ce qui brille}

Film français de Géraldine Nakache et Hervé Mimran

\section{André Videau}

1 Ely et Lila (Géraldine Nakache, la réalisatrice, et Leïla Bekhti) sont deux inséparables copines qui ont du mal à supporter d'avoir vingt ans à dix minutes de la vraie vie (durée du trajet Puteaux-Paris en RER).

2 Elles n'habitent pourtant pas une de ces banlieues repoussoir qui défrayent la rubrique des faits-divers et la chronique des sociologues urbains.

3 Même si les deux sont d'origine modeste, l'une juive et l'autre musulmane, cela ne pose pas, entre elles, le moindre clivage et leur franchissement du périph' n'est qu'une quête ludique des lieux où l'on s'éclate en transgressant allègrement les codes.

4 Voilà donc un petit film furtif, souvent désopilant, où la dénonciation de l'exclusion et des discriminations reste sous-jacente, sans jamais prendre des allures de revanche. Peut-être est-ce ce qui a plu ? La légèreté du propos, ajoutée à des répliques qui font mouche. La désinvolture naturelle des deux interprètes principales (auxquelles il faut ajouter Virginie Ledoyen, Linh-Dan Pham et surtout l'irrésistible Audrey Lamy).

5 Mention spéciale pour Leïla Bekhti, avec un nouveau rôle à sa mesure (après notamment Un prophète ou Mesrine), qui vient renforcer le contingent féminin des jeunes comédiennes issues de la "diversité", comme on dit. On avait souvent déploré l'état d'infériorité par rapport à la réussite numérique des garçons. Cette nouvelle révélation, qui s'ajoute à celle de Aïssa Maïga ou de Hafsia Herzi, commence à combler l'écart. 